\title{
Descritores em Ciências da Saúde na área específica da Fonoaudiologia Brasileira***
}

\author{
Health Sciences Descriptors in the Brazilian Speech-Language and \\ Hearing Science
}

\author{
Heliane Campanatti-Ostiz* \\ Claudia Regina Furquim de Andrade**
}

*Fonoaudióloga. Doutora em Ciências pelo Departamento de Fisioterapia, Fonoaudiologia e Terapia Ocupacional da Faculdade de Medicina da Universidade de São Paulo (FMUSP). Presidente da Pró-Fono Produtos Especializados para Fonoaudiologia. Endereço para correspondência: Rua Gêmeos, 22 - Barueri - SP - CEP 06473-020 (campanattiostiz@profono.com.br).

**Fonoaudióloga. Professora Titular do Departamento de Fisioterapia, Fonoaudiologia e Terapia Ocupacional da FMUSP.

***Parte da Tese de Doutorado ${ }^{1}$ apresentada à FMUSP para obtenção do Título de Doutor em Ciências

Artigo Original de Pesquisa

Artigo Submetido a Avaliação por Pares

Conflito de Interesse: não

Recebido em 17.06.2010.

Revisado em 21.10.2010; 24.11.2010.

Aceito para Publicação em 24.11.2010.

\begin{abstract}
Background: terminology in Speech-Language and Hearing Science. Aim: to propose a specific thesaurus about the Speech-Language and Hearing Science, for the English, Portuguese and Spanish languages, based on the existing keywords available on the Health Sciences Descriptors (DeCS). Method: methodology was based on the pilot study developed by Campanatti-Ostiz and Andrade ${ }^{2}$, that had as a purpose to verify the methodological viability for the creation of a Speech-Language and Hearing Science category in the DeCS. The scientific journals selected for analyses of the titles, abstracts and keywords of all scientific articles were those in the field of the Speech-Language and Hearing Science, indexed on the SciELO. 1. Recovery of the Descriptors in the English language (Medical Subject Headings - MeSH); 2. Recovery and hierarchic organization of the descriptors in the Portuguese language was done (DeCS). The obtained data was analyzed as follows: descriptive analyses and relative relevance analyses of the DeCS areas. Based on the first analyses, we decided to select all 761 descriptors, with all the hierarchic numbers, independently of their occurrence (occurrence number - $\mathrm{ON}$ ), and based on the second analyses, we decided to propose to exclude the less relevant areas and the exclusive DeCS areas. Results: the proposal was finished with a total of 1676 occurrences of DeCS descriptors, distributed in the following areas: Anatomy; Diseases; Analytical, Diagnostic and Therapeutic Techniques and Equipmente; Psychiatry and Psychology; Phenomena and Processes; Health Care. Conclusion: the presented proposal of a thesaurus contains the specific terminology of the Brazilian Speech-Language and Hearing Sciences and reflects the descriptors of the published scientific production. Being the DeCS a trilingual vocabulary (Portuguese, English and Spanish), the present descriptors organization proposition can be used in these three languages, allowing greater cultural interchange between different nations.
\end{abstract}

Key Words: Speech-Language Pathology; Speech, Language and Hearing Sciences; Terminology as Topic; Subject Headings; Periodicals; Vocabulary, Controlled.

\section{Resumo}

Tema: terminologia na Fonoaudiologia. Objetivo: proposição de tesauro específico sobre a Fonoaudiologia, nas Línguas Inglesa, Portuguesa e Espanhola, a partir dos descritores existentes nos Descritores em Ciências da Saúde (DeCS). Método: baseado no estudo piloto de Campanatti-Ostiz e Andrade², que teve por objetivo a verificação da viabilidade metodológica para a criação da categoria específica da Fonoaudiologia brasileira no DeCS. As revistas científicas selecionadas para análise dos títulos, resumos e palavras-chave foram as de Fonoaudiologia indexadas na SciELO. 1. Recuperação dos Descritores em Língua Inglesa (Medical Subject Headings - MeSH); 2. Recuperação e hierarquização dos descritores em Língua Portuguesa (DeCS). Foram realizadas a análise descritiva dos dados e a análise de relevância relativa das áreas do DeCS. A partir da primeira análise, decidiu-se pela participação de todos os 761 descritores levantados, com todos os seus números hierárquicos, independente de seus números de ocorrência (NO) e, a partir da segunda, optou-se pela exclusão das áreas menos relevantes e exclusivas do DeCS. Resultados: na proposição de tesauro da Fonoaudiologia, foram encontradas 1676 ocorrências de descritores DeCS, distribuídos nas áreas Anatomia; Doenças; Técnicas Analíticas, Diagnósticas e Terapêuticas e Equipamentos; Psiquiatria e Psicologia; Fenômenos e Processos; Assistência à Saúde. Conclusão: a proposição de tesauro apresentada contém os termos de domínio da Fonoaudiologia brasileira e refletem os descritores da produção científica das publicações pesquisadas. Sendo o DeCS um vocabulário trilingue (Português, Inglês e Espanhol), esta proposição de organização dos descritores poderá ser apresentada nestas três Línguas, propiciando maior intercâmbio cultural entre as diferentes nações.

Palavras-Chave: Fonoaudiologia; Terminologia como Assunto; Descritores; Publicações Periódicas; Vocabulário Controlado.

Referenciar este material como:

Campanatti-Ostiz H, Andrade CRF. Health Sciences Descriptors in the Brazilian Speech-Language and Hearing Science (original title: Descritores em Ciências da Saúde na área específica da Fonoaudiologia Brasileira). Pró-Fono Revista de Atualização Científica. 2010 out-dez;22(4):397-402. 


\section{Introduction}

The super-specialization has led professionals from different fields of knowledge to develop language and rationales very different from each other. The differences among these professionals provide differences and lack of communication among them3.

When a specific scientific community does not develop its own technical and scientific terms, this community is forced to use terminology from more developed areas for the communication of its contents 4.

According to Pereira-Silva et al.5, the facilitation of comprehension and communication among peoples of different cultures and nationalities is one of the searches of Science. The authors stress the importance of standardization and universalization of knowledge so that there is both the comparability and reproducibility of results of scientific studies among different peoples and the dissemination and exchange of information on specific topics.

Bocato6 reports that the information system is impaired when a documentary language of a specific Science is not compatible with the query language of the researchers inserted in this context and when it does not reflect that culture. In these cases, the impairment occurs in the quality of research and the effectiveness of documentary information retrieval.

Roberts and Souter7 report the high cost and time spent on manual indexing of documents in a database. The authors assume that a detailed analysis of textual features of the articles can be used on automated indexing of topics. The authors describe several relevant aspects to this automation and agree that the manual identification of descriptors of themes as the spread of automated search parameters are essential for indexing the information. The conceptual field of the term Descriptor is delimited according to Castro8: "Concepts extracted from a controlled vocabulary or thesaurus, which describe their contents. They can be composed by one or more words".

These authors7 present an automated indexing research of themes using software developed for this purpose - the terms from the titles and abstracts of scientific papers are treated and, subsequently, the equivalent descriptors are listed. This result of automated surveying of descriptors is compared with manual indexing carried out by experienced indexers from the Medical Literature Analysis and Retrieval System Online (Medine). The authors suggest the usefulness of automating the indexing of articles sent to feed databases, requiring the improvement of this automation system, both for better identification of correct descriptors and for the omission of incorrect descriptors. They conclude that although there is need for more studies and more techniques on the topic, the presented system can already be used for specific proposals.

As means to ensure its visibility, the journals should be indexed on national and international basis9. In this context, we cite the Brazilian SpeechLanguage and Hearing Sciences journals indexed on the databases National Library of Medicine (NLM) and/or Scientific Library Online (SciELO): Pró-Fono Revista de Atualização Científica10, Revista da Sociedade Brasileira de Fonoaudiologia11 e Revista Cefac Atualização Científica em Fonoaudiologia12. These two databases use the Medical Subject Headings (MeSH) and the Health Sciences Descriptors (DeCS) for indexing their documents.

The DeCS controlled and trilingual vocabulary (English, Portuguese and Spanish) was developed from the Mesh by the Latin American and Caribbean Center of Information in Health Sciences (BIREME) for the use in indexing articles from scientific journals, books, conference proceedings, among other materials, as well as for searching and retrieving themes from the scientific literature in the databases Lilacs, MEDLINE, and others. DeCS is a hierarchically structured vocabulary, i.e. is a conceptual and terminological tree that maps the knowledge of health sciences in order to present it in an organized manner, dividing it into categories and subcategories (or branches) and, within them, organizes the descriptors from more general to more specific 13.

In the global scenario of Speech-Language and Hearing Sciences, Regina Walsh (Speech-Language therapist president of Speech Pathology Association of Australia - SPAA), in collaboration with the International Group on Terminology Framework - Communication Sciences and Disorders (IGOTF - CSD), presents a document with a literature review on the history and relative youth of this Science14. Basically, the factors that contribute to the problems of terminology in SpeechLanguage and Hearing Sciences are: youth of the profession, the diversity of professional training, cultural and geographical differences, and also different opinions on how to improve this situation. Many authors comment on the complexity of the problems of terminology, but relatively few provide suggestions for solving the problem. The authors of the above mentioned document recognize that 
words and language are dynamic and apply this same principle to the terms of Speech-Language and Hearing Sciences. Therefore, it is placed the need to develop new strategies that take into account this dynamic role of the terms. Regarding the projects developed, the efforts to minimize the problems arising from historical and geographical diversities are presented. Finally, the authors argue that the terminology in Speech-Language and Hearing Sciences remains a significant challenge.

According to DeCS15, a new category may be created when one is facing: new knowledge field; knowledge field in which the DeCS terminology is insufficient; knowledge field in which the terms are to be dispersed through the existing categories.

Thus, the purpose of this study is the proposition of a specific Speech-Language and Hearing Sciences thesaurus based on the descriptors in DeCS, in English, Portuguese and Spanish, outlining here the conceptual field of the Thesaurus according to Young16: "Collection of words with synonymous terms, dependencies and hierarchical and of another type relationships, which function is to provide a standardized and controlled vocabulary for the storage and retrieval of information".

\section{Method}

This study was approved by the Ethics Committee of the School of Medicine, University of São Paulo (Protocol number 065/10).

The method described here is based on the pilot study by Campanatti-Ostiz and Andrade2 which proved to be an efficient tool for raising descriptors from titles and abstracts of scientific papers.

Material

1. Database: National Library of Medicine (NLM) and Scientific Library on Line(SciELO); Joumals and selected issues: Pró-Fono Revista de Atualização Científica10, Revista Cefac Atualização Científica em Fonoaudiologia12 e Revista da Sociedade Brasileira de Fonoaudiologia11 published on the 24 months prior to the study with a total of 24 issues analyzed.

3. Constituent parts of journal articles selected for the study and treatment of terms: titles, abstracts and keywords.

4. Sheet records: Protocol for Registration, Treatment and Analysis of Terms (Pretat) 1-2.
Procedures

The treatment of the terms selected from titles and abstracts in English was based on study developed by Roberts and Souter7.

The first phase of this study was to recover the keywords in the English Language(MeSH): identification and treatment of the terms of titles, abstracts and keywordsinEnglish(PhaseI-1;I-2; andI-3, respectively).

The second phase of this study consisted on the retrieval and ranking of keywords in Portuguese (DeCS): Phase II -1. Search in DeCS for the equivalent descriptors in Portuguese; Phase II - 2. Registration, identification and quantification of the hierarchical number of the identified DeCS descriptors; Phase II - 3. Data analysis.

From the descriptive analysis, it was decided to involve all 761 descriptors identified in this study, with all hierarchical numbers, independent of NO. From the analysis of relative relevance of areas on DeCS, we opted for the proposition of the thesaurus of Speech-Language and Hearing Sciences excluding the less relevant areas and exclusive areas of DeCS; Phase II - 4: Proposition of the distribution on the specific area of Speech-Language and Hearing Sciences of the identified descriptors. For the arrangement of descriptors collected in sub-areas of Speech-Language and Hearing Sciences, we used the hierarchy of the categories already proposed by DeCS. In order for all levels of the hierarchical structure to be covered (from the broadest to the most specific descriptors), the nonexistent descriptors were entered, along with their hierarchical numbers.

\section{Results}

The results obtained at the end of Phase I are displayed in Table 1.

In Phase II - 1, we found 3511 occurrences of descriptors on MeSH (average of 11.29 per descriptor) and 3492 occurrences of equivalent DeCS descriptors. Analyzing these 3492 occurrences, 761 different DeCS descriptors were found.

In Phase II - 2, 1624 hierarchical numbers different than those 761 DeCS descriptors were found - the same descriptor can have one or more hierarchical number, in the same or different areas of DeCS.

Descriptive analysis of the occurrence of descriptors carried out in Phase II - 3 can be seen in Figure 1. A normal distribution was not observed on the analyzed data; there is a predominance of descriptors with NO located within 1 or 2 SD below the mean ( $77 \%$ of the descriptors). The other descriptors (23\%) are sparsely distributed - up to $30 \mathrm{SD}$ above the mean such as a Child, Speech, 
Hearing, and Language, with NO of 89, 77, 70 and 68 respectively.

It should be stressed that the descriptors that were distributed between the mean and 2 SD below it (77\%) represent only $17.2 \%$ of the total number of occurrences (NO low: up to three occurrences per descriptor). However, these descriptors do have representation in terms of conceptualization and practice of this science: Respiratory System $(\mathrm{NO}=1)$; Suction $(\mathrm{NO}=1)$; Mental Retardation $(\mathrm{NO}=1)$; Conductive-sensorineural Mixed Hearing Loss $(\mathrm{NO}=1)$, among others.

The relative relevancy analysis of the areas of DeCS can be seen in Figure 2: the area of greatest relevance is C (Diseases) - relevancy index of $100 \%$. It was also noted that there is a group of five areas with relevancy index higher than 35\%, arranged in descending relevance order: E - Analytical, Diagnostic and Therapeutic Techniques and Equipments; G - Phenomena and Processes; F Psychiatry and Psychology; SP - Public Health; N - Health Care.
It can be observed still in Figure 2 that there is an area with a relevancy index of approximately $25 \%$ (A - Anatomy), suggesting that at least these first seven areas are relevant to Speech-Language and Hearing Sciences (areas C, E, G, F, SP , N, A). The other areas of DeCS have a relevance index of less than $20 \%$.

When eliminating the areas with relevance index of less than $20 \%$ (12 areas), the areas with no equivalent in MeSH (SP - 169 descriptors and 43\% of relevancy index), and adding the missing descriptors for complementation of hierarchal levels, the thesaurus of Speech in hierarchical levels (Table 2) is proposed - end of Phase II - 4. Excluding the repeated descriptors of the 1676 descriptors, 1024 were found, being that 375 (37\%) were insertions for complementation of hierarchical levels and 649 (63\%) were descriptors initially identified on the search.

TABLE 1. Availability of the number of terms and MeSH descriptors (and respective means) in Phases I - 1, I - 2, and I - 3 of the recovery of MeSH (English).

\begin{tabular}{l|c|c|c|c}
\hline $\begin{array}{c}\text { Number } \\
\text { of } \\
\text { Terms }\end{array}$ & $\begin{array}{c}\text { Mean } \\
\text { of } \\
\text { Term } \\
\text { s }\end{array}$ & $\begin{array}{c}\text { Number } \\
\text { of } \\
\text { MeSH } \\
\text { descript } \\
\text { ors \% }\end{array}$ & $\begin{array}{c}\text { Mean } \\
\text { of } \\
\text { MeSH } \\
\text { descri } \\
\text { ptors }\end{array}$ \\
\hline $\begin{array}{l}\text { Phase I - 1. } \\
\text { Identification } \\
\text { and treatment of } \\
\text { terms from the } \\
\text { title in English }\end{array}$ & 1209 & 3,9 & 1823 & \\
$\begin{array}{l}\text { Phase I - 2. } \\
\text { Identification } \\
\text { and treatment of } \\
\text { terms from the } \\
\text { ab stracts in }\end{array}$ & 2447 & & & \\
$\begin{array}{l}\text { English } \\
\text { Phase I - 3. }\end{array}$ & & & & \\
$\begin{array}{l}\text { Identification } \\
\text { and treatment of } \\
\text { terms from the } \\
\text { keywords in }\end{array}$ & 1319 & & & \\
English & & & & \\
TOT AL & & & & \\
\hline
\end{tabular}


FIGURE 1. Number of descriptors accord ing to the Number of Occurrence (NO) and standard deviations.

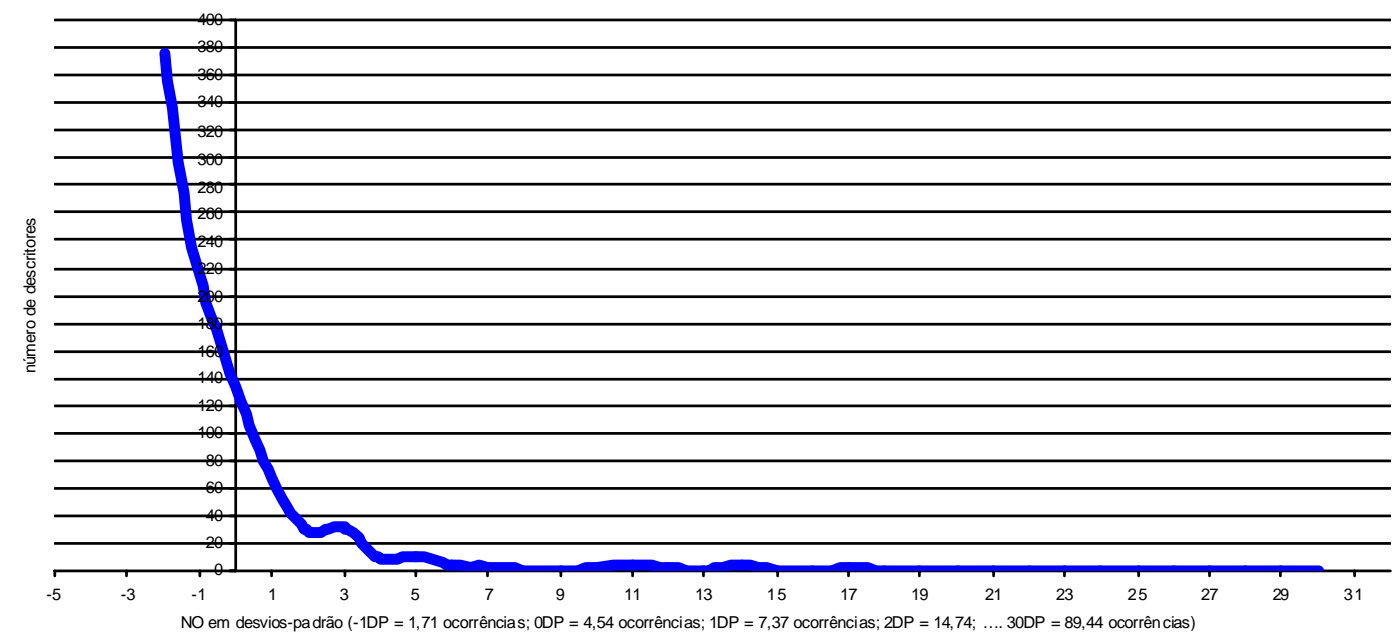

FIGURE 2. Percentage of occurrence of descriptors according to the areas of DeCS.

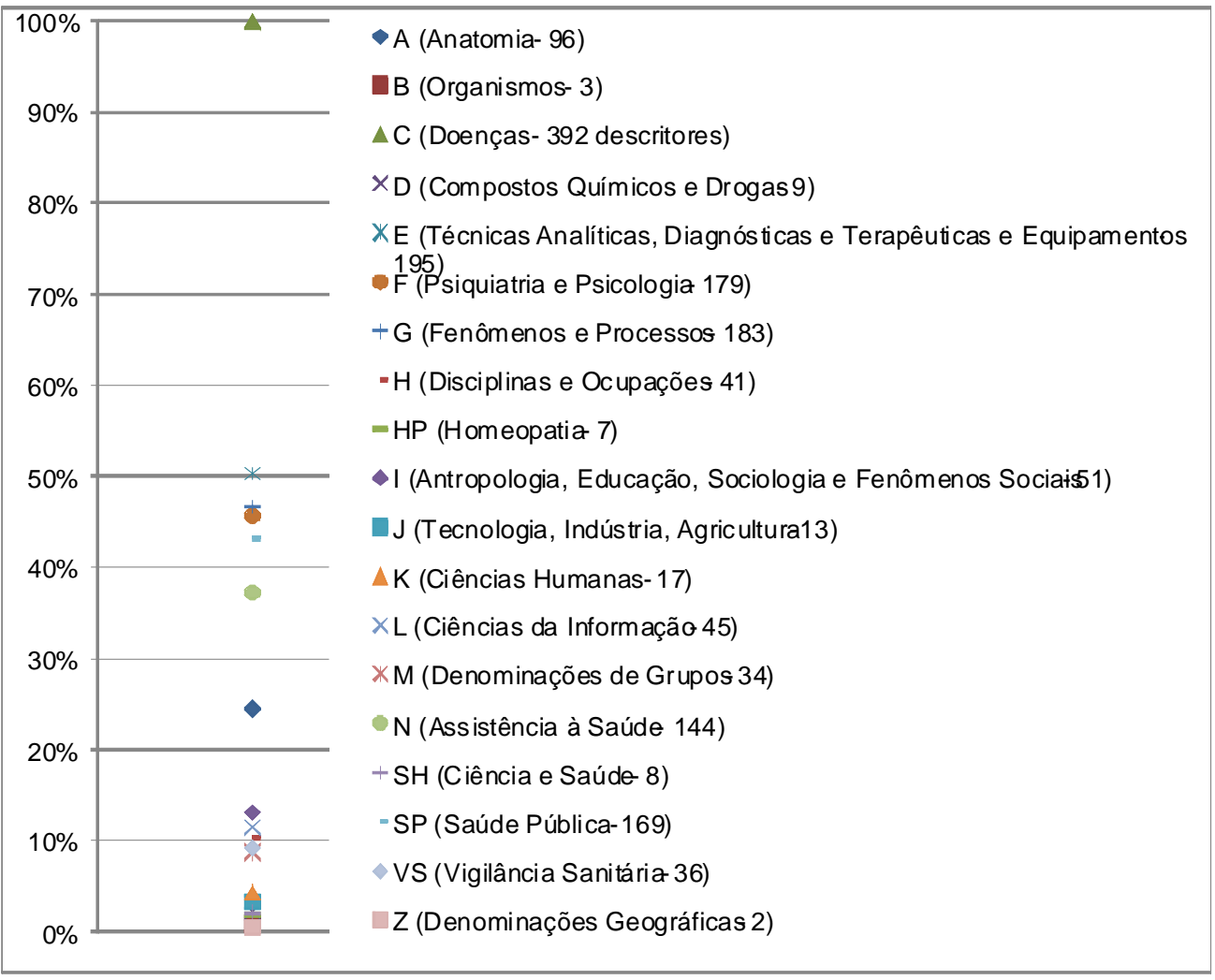

A - Anatomy; B - Organisms; C - Diseases; D - Chemical comp osites and Drugs; E - Analytic, Diagnostic and Therap eutic Techniques and Equipments; F - Psychiatry and Psychology; G - Phenomenon and Processes; H - Disciplines and Occupations; HP - Homeop athy; I - Anth ropology, Edu cation, Sociology and Social Phenomena; J - Technology, Industry, Agriculture; K Humanities; L - Information Sciences; M - Group Denomination s; N - Health Care; SH - Science and Health; SP - Public Health VS - Sanitary; Z - Geographic Denominations. 
TABLE 2. Areas selected for composition of the hierarchical structure of Speech, Language and Hearing Sciences, number of initially identified and added descriptors.

\begin{tabular}{|c|c|c|c|c|}
\hline & $\begin{array}{c}\text { Number } \\
\text { of } \\
\text { Terms }\end{array}$ & $\begin{array}{c}\text { Mean } \\
\text { of } \\
\text { Terms }\end{array}$ & $\begin{array}{c}\text { Number of } \\
\text { MeSH } \\
\text { descriptors } \\
\%\end{array}$ & $\begin{array}{c}\text { Mean of } \\
\text { MeSH } \\
\text { descriptor } \\
\text { s }\end{array}$ \\
\hline $\begin{array}{l}\text { Phase I - } 1 . \\
\text { Identification } \\
\text { and treatment } \\
\text { of terms from } \\
\text { the title in } \\
\text { English }\end{array}$ & 1209 & 3,9 & 1823 (31\%) & 6 \\
\hline $\begin{array}{l}\text { Phase I - } 2 \text {. } \\
\text { Identification } \\
\text { and treatment } \\
\text { of terms from } \\
\text { the abstracts } \\
\text { in English }\end{array}$ & 2447 & 7,9 & 2549 (43\%) & 8,2 \\
\hline $\begin{array}{l}\text { Phase I - } 3 \text {. } \\
\text { Identification } \\
\text { and treatment } \\
\text { of terms from } \\
\text { the keywords } \\
\text { in English }\end{array}$ & 1319 & 4,2 & $1514(26 \%)$ & 4,9 \\
\hline Total & 4975 & 16 & 5886 & 20 \\
\hline
\end{tabular}

\section{Discussion}

The method proposed in this study proved to be adequate to the research proposal; we found an average of 11.29 different descriptors per article after analyzing the titles, abstracts and keywords.

The analysis of the titles suggests an average of six descriptors for each article title analyzed. This result supports the assertion of Roberts and Souter7 that terms of the titles of documents are essential to the indexing process and should be carefully proposed.

The analysis of abstracts indicated an average of 8.2 descriptors per article abstract. However, it is noteworthy that the larger the abstract, the greater the chance of a word being repeated three or more times. In short abstracts, the repetition of the same word at least three times did not usually occurred, making it impossible, according to the proposed method, the search for a descriptor equivalent in MeSH.According Guimarães17, with exception of the title, the abstract of a scientific publication is the part that will be read by most readers. Thus, the number of words allowed by the journals in their Guidelines to Authors should be sufficient to provide data to support the indexing process.

On the analysis of keywords in English, which were not analyzed in the present study, we observed that 181 keywords (13.72\%) were not MeSH descriptors, contrary to the Guideline to Authors from the three journals analyzed. If all authors had followed these instructions, the 1319 keywords identified would have correlated exactly the $1319 \mathrm{MeSH}$ descriptors. In an article published by Pellizzon et al.18, the authors analyzed the instructions to authors of 20 journals that publish articles on Surgery. The editors were alerted to the internationally accepted criteria that must be observed, but that advances on the flow of scientific communication requires the participation of all involved in the process of scientific production.

According to DeCS19, MeSH and DeCS update their descriptors annually, requiring the review and updating of the search strategies of thematic BVL. Thus, the nomenclature of the descriptors presented here represents the period of application of study. Further studies on the subject will present, indeed, a different configuration. An example of this difference is that the descriptor "Vocal Cords" observed in the current study has already been changed to "Vocal Fold."

Still regarding the dynamic terminology update, the proper descriptor Speech-Language and Hearing Sciences did not exist in DeCS in the years 2008 and 
2009. This descriptor was inserted on the update performed by DeCS in 2010 - however, there is no equivalent MeSH descriptor. All DeCS descriptors with equivalence on $\mathrm{MeSH}$ have on its record the field identifier (ID) - the descriptors Speech-Language and Hearing Sciences on DeCS does not have ID. This descriptor was inserted into the area $\mathrm{SH}$, Science and Health, developed by DeCS in 2005 - also an area with no equivalent in MeSH. The English translation provided is "Speech, Language and Hearing Sciences" which, if searched on MeSH, does not exist. Thus, the occurrence of scientific papers available in international databases will be impaired, both when using the descriptor "Speech-Language and Hearing Sciences (Fonoaudiologia)" as the descriptor "Speech, Language and Hearing Sciences."

The relevancy analysis of areas conducted in the current study was important for the selection of areas in order to compose the proposition of the hierarchical structure of Speech-Language and Hearing Sciences. The proposal was finalized with a total of 1676 occurrences of DeCS descriptors: 1189 occurrences (71\%) resulting from descriptors collected during the search and 487 occurrences (29\%) resulting from descriptors added to complement levels.

It can be inferred that the analysis of relevance of the areas was efficient: a proposition of Speech, Language and Hearing Sciences thesaurus contains 1024 different DeCS descriptors; from this total of 1024 different DeCS descriptors, 649 (63\%) were identified on the search (they are not the DeCS descriptors inserted to complement all hierarchical levels); from the initial sample of 761 different DeCS descriptors (Table 2) distributed in all areas of DeCS, 649 (85\%) were used for the composition of thesaurus proposition of Speech, Language and Hearing Sciences; from the initial sample of 761 different DeCS descriptors (Table 2), only 112 (15\%) were eliminated by excluding the non relevant and exclusive DeCS areas.

\section{Conclusion}

The thesaurus proposed as a result of the present study contains the descriptors of Brazilian Speech-Language and Hearing Sciences and

\section{References}

1. Campanatti-Ostiz H. Descritores em ciências da saúde na área específica da Fonoaudiologia brasileira [tese doutorado]. São Paulo: Faculdade de Medicina, Universidade de São Paulo; 2010. 2606 p. [Corpus e Apêndices em CD]. reflects the descriptors of the scientific production of selected publications during the 24 months of validity of research data.

As DeCS is a trilingual vocabulary (English, Portuguese and Spanish), this proposition of descriptors may be presented in these three languages and contribute to the unification of such vocabulary. As all DeCS descriptors proposed here have their translation into Spanish language and their equivalent descriptors in $\mathrm{MeSH}$, this research will contribute to increasing both visibility of published works on international databases and the effectiveness of literature searches in the area, allowing greater cultural exchanges among different nations.

The study proposal did not include the analysis of the terms used in the scientific production of Brazilian Speech Language and Hearing Sciences that did not pertain to DeCS and was not extended to propose a new distribution of the descriptors of Speech Language and Hearing Sciences. However, the base consolidated here could facilitate the indexing and retrieval of information among users of databases using MeSH and /or DeCS as thesaurus.

The objective was achieved through the proposition of a specific thesaurus of Speech, Language and Hearing Sciences in English, Portuguese and Spanish, from existing descriptors in DeCS.

The study results may significantly contribute to the existing arrangement of descriptors in MeSH and DeCS. It is hoped that the studies being developed by the International Group on Terminology Framework Communication Sciences and Disorders (CSDIGOTF) 14, in partnership with the International Association of Logopedics and Phoniatrics (IALP) and the Comité Permanent de Liaison des Orthophonistes/Logopèdes - Standing Liaison Committee of Speech and Language Therapists (CPLOL) succeed in their terminology and conceptual presentation of the Speech Language and Hearing Sciences.
2. Campanatti-Ostiz H, Andrade CRF de. Descritores em Ciências da Saúde na Área Específica da Fonoaudiologia Brasileira: estudo piloto. In: Congresso Brasileiro de Fonoaudiologia, 16; 24 a 27 de Setembro de 2008, Campos de Jordão (SP). Resumos... [on line]. Campos de Jordão (SP): Sociedade Brasileira de Fonoaudiologia; 2008 [citado em: 7 jul 2009]. Disponível em < http://www.sbfa.org.br/ portal/anais2008/ >. 
3. Meis L de. Ciência, educação e o conflito humanotecnológico. 2. ed. rev. ampl. São Paulo: Senac; 2002. 145p.

4. Unesco. United Nations Educational, Scientific and Cultural Organization: guidelines for terminology policy in language communities [on line]. Paris: United Nations Educational, Scientific and Cultural Organization, 2005 [citado em: 16 maio 2005]. 39p. Disponível em: http:// unesdoc.unesco.org/images/0014/001407/140765e.pdf>.

5. Pereira-Silva JL, et al. Consenso brasileiro sobre a terminologia dos descritores de tomografia computadorizada do tórax. J. Bras. Pneumol. (São Paulo) [periódico on line]. 2005 [citado em: 03 set 2008]; 31(2). Disponível em: $<\mathrm{h} \mathrm{t} \mathrm{t} \mathrm{p} \mathrm{:} \mathrm{/} \mathrm{/} \mathrm{w} \mathrm{w} \mathrm{w.} \mathrm{s} \mathrm{c} \mathrm{i} \mathrm{e} \mathrm{l} \mathrm{o} \mathrm{.} \mathrm{b} \mathrm{r} \mathrm{/}$ scielo.php? script =sci_arttext \& pid=S 1806 37132005000200011\&lng=pt\&nrm=iso $>$. [Doi: 10.1590/ S1806-37132005000200011].

6. Boccato VRC. Avaliação de linguagem documentária em Fonoaudiologia na perspectiva do usuário: estudo de observação da recuperação da informação com protocolo verbal [dissertação]. Marília (São Paulo): Faculdade de Filosofia, Universidade Estadual Paulista; 2005.

7. Roberts D, Souter C. The automation of controlled vocabulary subject indexing of medical journal articles. Aslib Proceedings. 2000;52(10):384-401.

8. Castro RCF. Palavras-chave: seleção e atribuição. In: Curso de Editoração Científica, 10, 2001, Atibaia. Resumos... Rio de Janeiro: Associação Brasileira de Editores Científicos; 2001.

9. Lara MLG de. Termos e conceitos da área de comunicação e produção científica. In: Poblacion DA, Witter GP, Silva FFM. Comunicação e Produção Científica: contextos, indicadores e avaliação. São Paulo: Angellara; 2006. p. 387-414.

10. Pró-Fono Revista de Atualização Científica. Barueri (SP): Pró-Fono, 1989- . Semestral até 2001. Quadrimestral até 2002. Trimestral a partir de 2007. ISSN 0104-5687

11. Revista da Sociedade Brasileira de Fonoaudiologia. São Paulo: SBFa, 1997- . Semestral até 2002. Trimestral a partir de 2003. ISSN 1516-8034.
12. Revista Cefac Atualização Científica em Fonoaudiologia. São Paulo: Revinter, 1999- . Semestral até 2001. Quadrimestral em 2002. Trimestral a partir de 2003. ISSN 1516-1846.

13. Bireme. DeCS: descritores em ciências da saúde [online]. São Paulo: Bireme; s.d. [citado em: 6 maio 2010]. Disponível em: < http://decs.bvs.br/P/decswebp.htm>.

14. Speech Pathology Australia. A History of Terminology: International Group on Terminology Frameworks Communication Science and Disorders [on line]. Melbourne: Speech Pathology Australia, 2006 [citado em: 13 jun 2009]. Disponível em:< http:// Www.speechpathologyaustralia.org.au/resources/ terminology-frameworks-projects>.

15. DeCS. DeCS: descritores em ciências da saúde [on-line]. São Paulo: Bireme; fev. 2010 [citado em: 10 mar 2010]. Disponível em: http://decs.bvs.br/P/decsweb2010.htm>.

16. Young H, editor. Glossario ALA de bibliotecología y ciencias de la informacion. Tradução de Blanca de Mendizabal Alende. Madrid: Días de Santos; 1983.

17. Guimaraes CA. Structured abstracts: narrative review. Acta Cir. Bras. (São Paulo) [periódico on line]. 2006 Aug [citado em: 16 maio 2010]; 21(4). Disponível em: <http:/ /www.scielo.br/scielo.php?script=sci_arttext\&pid=S0102$86502006000400014 \& \operatorname{lng}=$ en \&nrm $=$ iso $>$.

18. Pellizzon RF, Montero EFS, Poblacion DA, Monteiro $\mathrm{R}$, Castro RCF. Revistas brasileiras publicadoras de artigos científicos em cirurgia; III: análise das instruções aos autores baseada na estrutura dos requisitos de Vancouver. Acta Cir. Bras. (São Paulo) [periódico on line]. 2007 Nov-Dec [citado em: 15 jun 2010]; 22(6): [10 telas]. Disponível em:< http:/ /www.scielo.br/scielo.php?script=sci_arttext\&pid=S010286502007000600016\&lang $=p t>$.

19. Guia para a criação de categoria terminológica no decs. Biblioteca Virtual em Saúde [on-line]. ed. 2005. São Paulo: Bireme; 2005 [citado em: 27 nov 2009]. Disponível em: < h t t p : / / d e c s - c y s.bvs a l u d . org / P / Guia_para_Criacao_de_Novas_Categorias_no_DeCS.htm>. 